\title{
THE EMOTIONAL-MOTIVATIONAL COMPONENT OF SCHOOL READINESS OF BEGINNING PUPILS
}

\author{
Radka Teleková $^{1}$, Tatiana Marcineková $^{2}$
}

\begin{abstract}
A child's wish to become a pupil is one of the important identifiers of his / her school readiness. Its assessment at the beginning of schooling provides a picture of the child's initial ability at the beginning of the first year of study in primary school. The focus of this article is the motivational component of school readiness, which has an impact on the individual form of adaptation of beginning pupils. The subject of the research was to find out the presence of individual motives in the structure of the emotional-motivational component of school readiness of children at the beginning of school attendance. The defined component consists of social, cognitive and moral motives, which are interconnected. We were used a questionnaire with ten items in the research activity. The respondents were pupils of the first year of study in selected elementary schools. The results showed that the social, cognitive and moral motive were presented within the emotional-motivational component of school readiness. Overall, there were positive answers to the three motives, which showed a high level of motivation in the research sample. The level of the emotional-motivational component of becoming a pupil is one of the elements ensuring the successful adaptation of the pupil at the beginning of school life. Strengthening the incentive to become a pupil, deepening the desire to learn new things and shaping social skills for existence in the classroom are seen as a tool for developing the motivational sphere of school readiness.
\end{abstract}

UDC Classification: 37, DOI: https://doi.org/10.12955/pss.v1.76

Keywords: school readiness, adaptation, motivation, emotional-motivational component,

\section{Introduction}

The entry of children into the first year of elementary school is a challenging period, which requires a number of questions to be addressed in both theoretical and practical sides. One of them is the issue of the child's readiness to successfully enter to the new school environment. The point is that the quality of school start-up affects the success of the pupil's entire school career and the development of his / her personality (Bezrukich and Jefimovova, 2000; Vilchinskaya, 2000; Griebel and Niesel, 2000; 2001; Fabian and Dunlop, 2007; Matthews, 2008; Fabian, 2012). The countenance of this issue is underlined by the fact that the number of children who fail at the beginning of schooling is increasing. Adaptation difficulties are discovered, the failure of which may result in childrens' academic failure and later failure to meet their personal goals (Marko,1971;Vágnerová, 1997; Kovalevová and Tarasenko, 2001;Burvyté, S. 2011). In this context, it is necessary to address the issue of successful entry of a child to school comprehensively to involve all participating - teachers in kindergartens, in the first years of primary schools, psychologists, sociologists, but also experts in the field of legislation, and of course the parents of the children. In our article we want to focus on the issue of school readiness of children from the perspective of innovative selected approaches to the definition of the school readiness criteria of future schoolchildren.

\section{Innovations in the criteria of school readiness}

The time needed to adapt the child to the significant changes associated with the start of schooling is individual and is also related to his or her school readiness. This represents the result of mental, emotional, social, physical readiness to receive, process and use the impulses of the school's educational environment and beyond. The requirements for the child's school readiness vary depending on changing societal conditions, society's expectations in relation to the quality of the individual, as well as current trends in education determined by the philosophy of the school, but mainly the latest research in pedagogy, psychology, sociology, neuropedagogy but also the economy.

There are several concretizations of its content in the literature. Borbélyová (2014) refers to selected authors (Geréb,1976; Ádám, 2000; Valachová, 2009; In: Borbélyová, D. 2014). Halle et al. (2012) accentuates the multidimensionality of school readiness and based on theoretical and research conclusions of selected authors, they describe five development domains related to pre-school preparation: the physical state and development, socio-emotional development, approaches to education, language development, cognitive and general knowledge. Slezáková and Borbélyová (2013) characterize the individual components of school readiness according to Babajevová (1990, In:

\footnotetext{
${ }^{1}$ Constantine the Philosopher University in Nitra, Faculty of Education, Department of Pedagogy, Nitra, Slovakia, radka.telekova@ukf.sk

${ }^{2}$ Constantine the Philosopher University in Nitra, Faculty of Education, Department of Pedagogy, Nitra, Slovakia, tmarcinekova@ukf.sk
} 
Slezáková and Borbélyová, 2013). The author defines the dynamic unity of four of its components: emotional-motivational, content-meaning, operational-activity and control-regulatory. These components are defined as a set of interdependent dimensions of school readiness. The starting point for their definition is the new position of the child in society, which he gains by adopting a new socially obligatory role of a scholar.

\section{Structure of emotional-motivational component of school readiness}

In our contribution we want to draw attention to the emotional-motivational component of the child's school readiness, which is concretized mainly by the child's social, cognitive and moral motive. In this context, we understand the motive as an incentive to encourage individual behavior. Cognition and orientation in the individual motives of the child becomes the starting point for the development of motivational dispositions that influence the school success, performance and development of pupils' personality.

Before entering the first year of primary school, the child has certain ideas about the school. Child's ideas become the starting point for forming an image of the future role of the pupil, which implies building a relationship with the school. Of course, in the pre-school period these ideas have a symbolic character. The positive expectation of the school is concretized by the contrasting perception of the role of the pupil and the previous role of the kindergarten child. Slezáková $(2009$,$) talks about the personality$ qualities and characteristics of a pre-school child, who are mainly related to "shaping an adequate picture of I-future scholar" and contributing to the success of adaptation to primary school.

A child who is ready for learning at school is looking forward to school, ready to take a new position in society that will allow him to enter the adult world (social learning motive). The social motive is in the structure of Babajevová (1990, In: Slezáková and Tirpáková 2006) expressed by the child's desire to become a pupil. At the same time, he has a need to get to know a new preschool way of life and kindergarten no longer satisfies him. The combination of both needs determines the emergence of a new nature of the child's relations with the outside world, which Božovič (1968) called the "internal position of the pupil". The internal position of the pupil is created at the interface between pre-school and a younger school age. It is characterized by a child's relationship to school, to learning tasks, to the teacher, and to school standards and rules. The future learning activity is perceived by the child as socially recognized (representing a new adult picture of life). In connection with this, his self-awareness, motivational sphere and forms of behavior are changing. Elkonin (1988) divided the formation of the inner position of the pupil into three levels:

1. A child who reaches the first level shows a positive attitude to school but is unaware of the content of the learning activity (he wants to go to school, but still maintain a pre-school way of life). The school associates with school attributes, e.g. backpack school supplies. He is not aware of school forms of teaching and school rules, the new nature of relationships with teachers and classmates. His "real self" does not differ from the "ideal self" (the child does not know how to correlate his / her real achievement).

2. The second level is characterized by the child's orientation to the essential aspects of school life. At this level, social rather than learning aspects are preferred. The child's "social self" is beginning to form (the child is aware of its new status, which implies a different position among other people). He begins to understand that he is expected to perform for which he will be assessed and accepted by others (classmates, parents and other adults).

3. The child who reaches the highest - third level shows interest in the social and teaching aspects of school life, with cognitive motives dominating.

At the beginning of school, there are children in the first two levels. In most cases, the last level will be reached in the second year of primary school (Polivanova, 2009).

Children who have an adequate level of inner position of the pupil and are able to adapt to the new school conditions without any difficulty, are able to meet the teacher's requirements, respect the set rules, find a suitable position among schoolmates and gradually identify with the scholar's role. This means that the child is able to take the position of the subject of the learning activity.

A pupil at the beginning of school wants to learn and know a lot. In the context of the presented structure of school readiness, the need for something new to learn is the essence of the cognitive motive of the 
emotional-motivational component. Working with the oldest age group in kindergarten presupposes the development of cognitive interests and curiosity of the child, motivation to acquire new knowledge and to learn, the school as a whole. (Slezáková, 2012) Kasáčová and Cabanová (2011) rank motivational assumptions as part of socio-affective assumptions on indicators of school readiness diagnosed at the beginning of schooling. Their content is related to the pupil's interest in learning, school activities, adequate enjoyment of joy and responsibility, by shaping the will characteristics to achieve school success.

The specifics of the motivation of future pupil include fulfilling the desire to be a good pupil. The fulfillment of the expectations of adults in the family and school environment becomes a prerequisite. The content refers to Babajevová (1990, In: Slezakova and Tirpakova 2006) as a moral motive of the emotional-motivational component of school readiness. We see importance in the individual experience of the feeling of success, which is the formed self-image in learning. The family acts as a tool to support the education of children and their motivation to learn, which is concretized by a suitable learning environment at home, by a clear expression of expectations, by providing opportunities, conditions and resources for their own education (Boethel, 2004).

The starting point for the support of pupils' motivation at the beginning of their schooling is the satisfaction of their basic needs, which also determines the success of adaptation to new conditions. Franclová (2013) emphasizes in particular the need for safety, which allows for a quiet focus on schoolwork. Successful transition to primary school requires pupils to feel fearless, relaxed and comfortable. The feeling of security has an impact on adapting to the new conditions at the beginning of school (Astbury, 2009). The level of motivation and school success is also influenced by the social needs that are present in the relationships between the actors in the educational process, the social climate and in the process of socializing the beginning pupil. One of the changes at the beginning of school attendance is an objective assessment of performance according to set criteria. The adaptation period also covers performance needs, building an optimum attitude to performance and its evaluation. The curiosity of children stimulates the satisfaction of cognitive needs, which are specifically focused on reading, writing and counting in the 1st year. For pupils, they become the starting point for raising the cognitive level, with an emphasis on the meaningful learning in everyday life.

\section{Data and Methodology}

The research part is focused on individual motives, which are the essence of the emotional-motivational component of school readiness. The subject of our research interest is the social, cognitive and moral motive that condition the school motivation and consequently the success of the pupil's adaptation. The main aim of the presented study was to determine the presence of individual motives within the emotional-motivational component of school readiness. For the purposes of the research, a research problem was formulated, which is concretized by the research question: What is the individual presence of individual motives in the structure of the emotional-motivational component of school readiness among beginning pupils?

The method of data collection was a questionnaire with ten items focused on social, cognitive and moral motives. The questionnaire belongs to the frequent research methods. This research tool makes it possible to obtain data from many respondents. Respondents express their own opinion, attitude to individual items, which generally affects validity and reliability (Gavora, P. 2012). The questionnaire was filled in by pupils of the 1st year who answered the questions by choosing from three variants of the answer. Due to the age group of children, the questions and answers were also read to everyone. The answers of each student, the respondent was recorded in writing. A positive answer means consent, a positive attitude within school motivation. The opposite is a negative answer. The options "I don't know, how-when, sometimes" represent a neutral answer. The items were gradually read to the pupils in a group interview and their answers individually recorded in writing. The questionnaire was specifically designed for the needs of this study and complied with the characteristics of the beginning pupils. For the purposes of the research, the selection of the research sample was made through the available selection and its intention was to determine the group according to the set criteria - age, education. The research sample consisted of 77 first-year pupils in selected elementary schools in the Slovak Republic (in the Nitra region, in the district of Topol'čany). The research study was carried out at the beginning of the second half of the school year. 
The course and duration of a pupil's adaptation at the beginning of school attendance is conditioned by the level of school readiness. Assessing the emotional-motivational component of school readiness is important not only before and at the beginning of schooling, but also later. School motivation is related to the course of adaptation and the occurrence of adaptation difficulties, which individually involves a longer period. The problems of a child's adaptation to school are related to school motivation, which affects school success and further school education. Based on research findings, T. Slezáková (2006) reports a longer duration of adaptation and the occurrence of adaptation difficulties for insufficiently prepared children.

The obtained data were processed according to their focus on individual motives of the emotionalmotivational component. Based on the number of responses, the arithmetic mean of the positive, neutral and negative responses within the social, cognitive and moral motive was determined. The representation of the representative value obtained is expressed by means of a graph for each motive of the emotional-motivational component. The results obtained include a brief description of the most relevant findings relating to the individual motives, based on the answers to the related questions.

\section{Results}

The items for determining the level of social motive related to the relationship to school and social relationships in the classroom are based on the characteristics of the role of the pupil and classmate. We asked pupils: Do you happily go to school? One of the items from the questionnaire was: Do you have friends among your classmates?

Pupils also expressed their attitude to the situation that they do not have to go to school tomorrow.

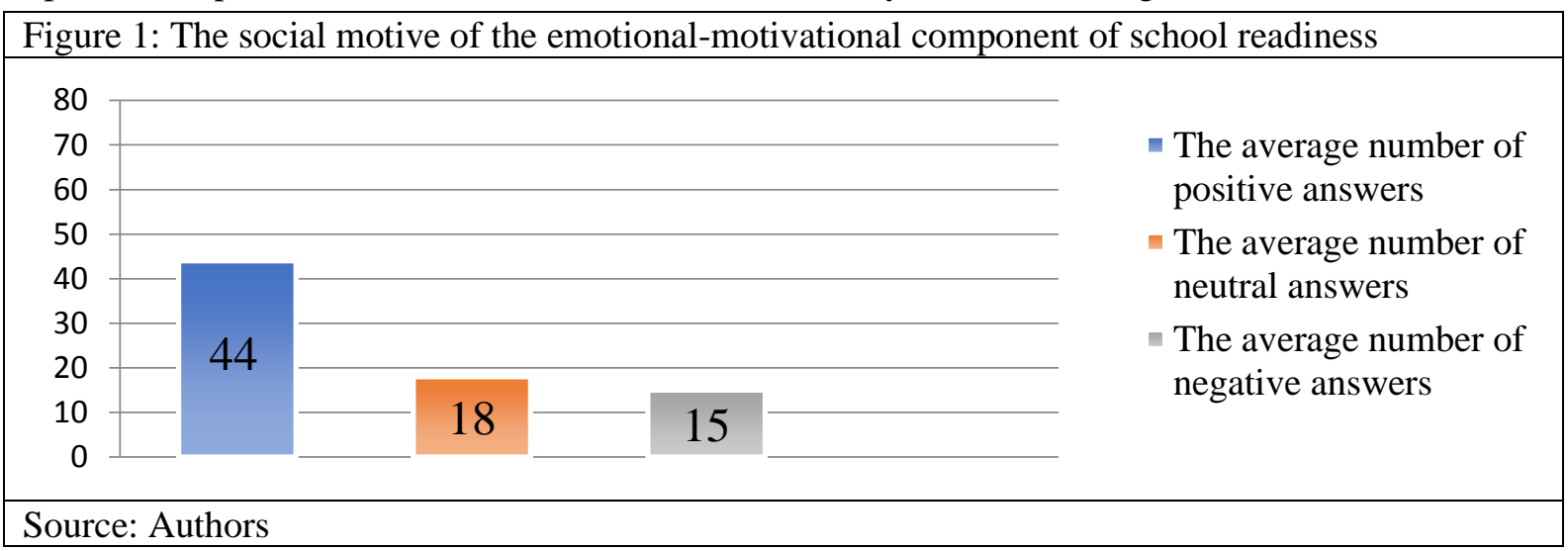

Figure 1 shows that an average of 44 pupils responded positively to school motivation. The relationship to school forms the perspective of a child in a new role. Knowing the individual reasons for experiencing joy becomes an instrument of motivation. The answers show that up to 56 pupils are happy to go to school and enjoy it at school. At the start of schooling, the child must be prepared for the existence and establishment of new contacts that result from the role of a classmate. On average, 18 responses represented a neutral choice, most frequently present in the question of classmates' friends, in the specification of "yes, but only someone", with the spontaneous appointment of a 1-5-member friend group. Pupils have created an acceptable position among classmates, they are part of the class team. Negative answers were chosen by an average of 15 pupils, with no answer "no, I have no friends in class". In the close-up situation, "if all pupils do not have to go to school tomorrow", 29 pupils would choose to stay at home, but 31 positive answers mean dominating the choice of attending school.

The cognitive motive was concretized in the items focused on learning, reasons for joy at school, home preparation, attitudes to acquiring new curriculum and subject matter. We asked pupils what they enjoy most at school and what is their favorite subject. We found out if they enjoyed new learning. The cognitive motive includes home preparation of beginning pupils. We asked pupils: Do you do homework every day and prepare for school regularly?

Figure 2 shows that an average of 46 pupils chose positive answers to the questions. The least of these were in the answer "when we learn", as the question "What makes you happy at school?" Was chosen by pupils, especially in the school or in a circle. Pupils perceive learning as a contrasting activity to the previous games that dominated kindergarten. Understanding the content of teaching activities 
contributes to shaping the internal position of the pupil at school. A nearly complete research sample of pupils has their favourite teaching subject, which they could subsequently name individually. Its existence is the starting point for individualization in the classroom in the process according to the pupils' interests. On average, 17 pupils responded neutrally. In the negative answers, on average 14 pupils commented mainly on unpopular homework and preparation for school, the desire to dominate the game over learning at school. Although pupils want to go to school, they would retain a pre-school way in individual activities involving the absence of homework.

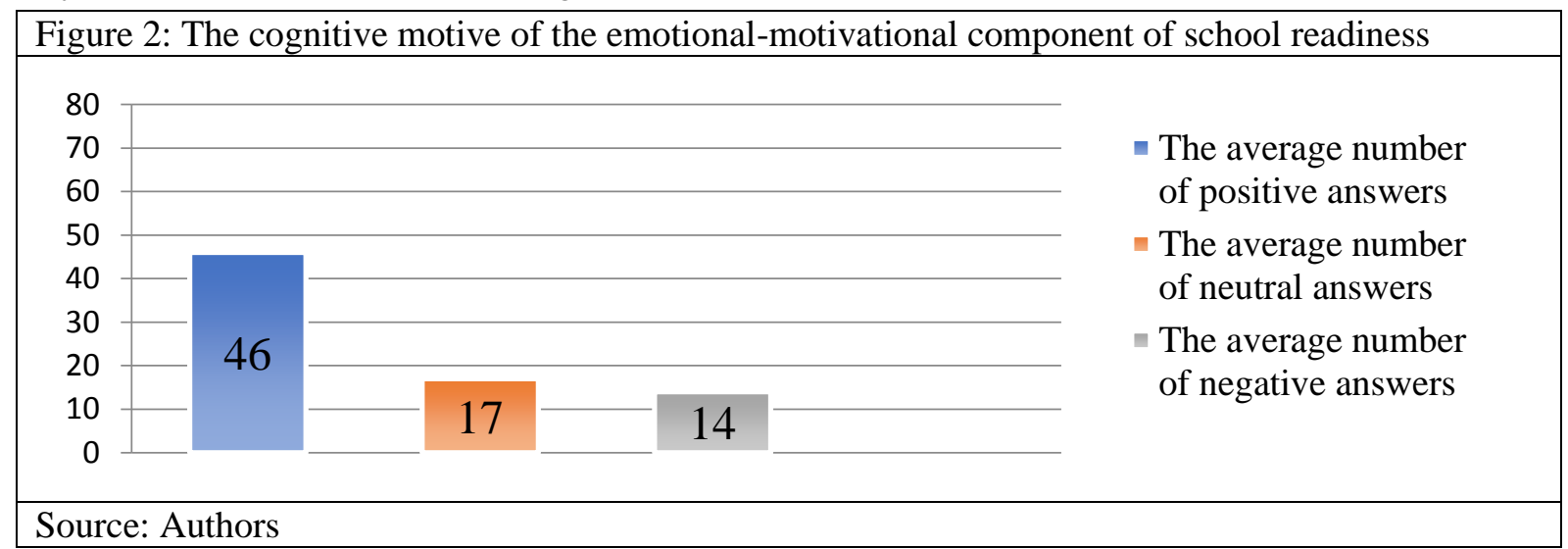

The range of questions for assessing the moral motive was focused on pupil sharing of the school with parents, awareness of positive feedback from parents or grandparents, adherence to pupil rules. In the questionnaire, we found out whether the pupils talk to their parents about the school and follow the rules of the pupils at school. We also asked the pupils: Do your parents or grandparents praise you and support you in your learning?

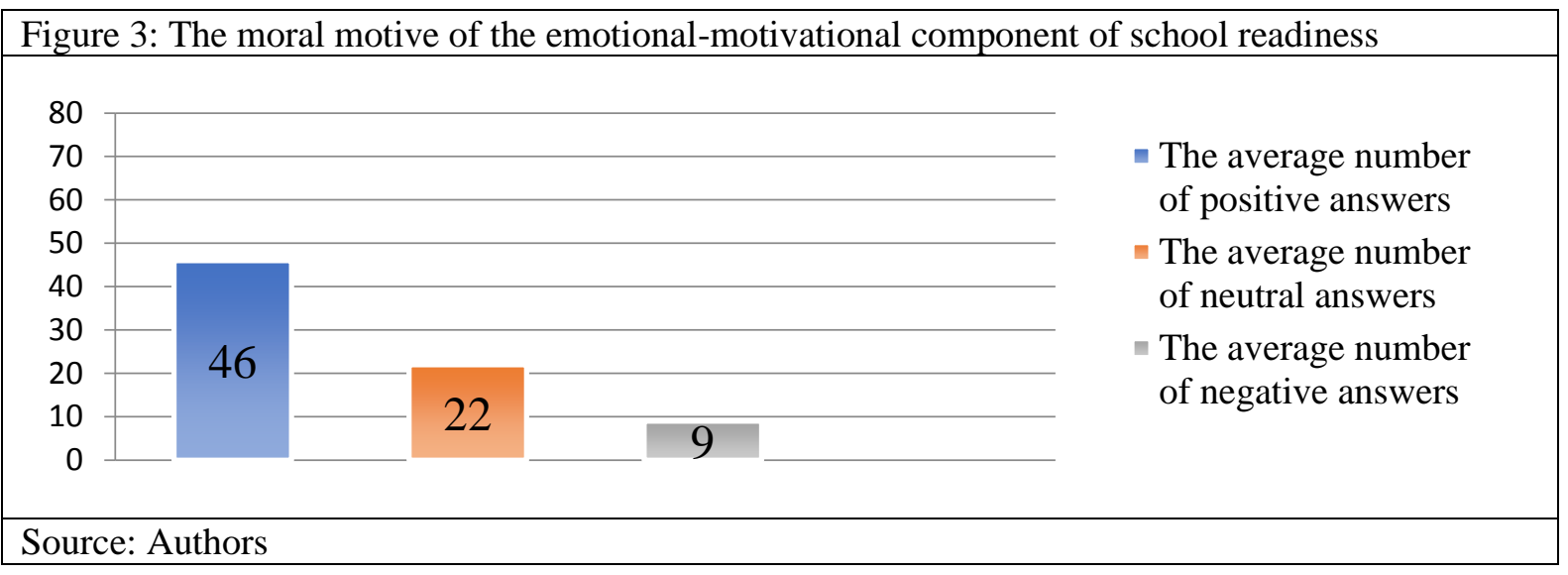

The average number of first-year responses in Figure 3 reflects the dominance of positive responses, which were recorded in an average of 46 pupils. The start of school education brings new responsibilities that require the necessary interpretation by parents and teachers. The child should be prepared that at school he will not always only succeed and that there will be more difficult and less pleasant situations. Managing stressful situations requires the pupil's own efforts and adequate adult support. When asked about adult assessment, up to 61 pupils stated that parents or grandparents praise and support learning. In addition, 30 pupils opted for a neutral "neither no" option and almost the same number responded neutrally to adherence to school rules like the "sometimes, than ever" option. On average, 22 pupils answered neutrally to the questions. On average, 9 pupils opted for negative options, expressing total disagreement with the question. Pupil statements show that 12 pupils do not tell parents about school at all, 8 pupils are not praised by parents at all and the same number of pupils admit absolutely noncompliance with scholar rules. A lack of respect for school rules can cause difficulties in learning for a pupil and hinder the process of identifying with the role of a scholar.

\section{Discussion}

Comparing the number of average responses of individual motives confirmed their presence in the structure of the emotional-motivational component of school readiness in beginning pupils. The social, 
cognitive and moral motive is equally represented after the first semester of pupils schooling. In the structure of the defined component of school readiness, they are interrelated and conditional. Confirming their presence in the first year allows the teacher to create suitable conditions for each child. We consider the representative values determined for the given answers to be comparable. At the same time, the dominance of positive responses to the three motives shows a high level of an emotional-motivational component of school readiness in the research sample of 1st year pupils. Individual motives are shaped at the optimum level for pupils and show their efforts to successfully carry out teaching activities and school requirements. In terms of the internal position of the pupil at school, the second level is mainly represented, although an individual assessment reveals the presence of the first level in some pupils from the research sample. The main objective of the presented study was fulfilled; the implementation of the questionnaire and the interpretation of research data revealed the presence of individual motives in the structure of the emotional-motivational component of school readiness.

\section{Conclusion}

The start of school attendance is accompanied by many changes that place specific requirements on the child, family, preschool and school environment. Kindergarten encourages the child's desire to become a pupil through artificial or spontaneous situations. Everyday family experience is a tool for developing the child's motivational sphere, the level of which is part of individual school readiness. At the beginning of school attendance, it is considered a "starting readiness", which has an impact on the pupil's adaptation, school success and further development of his / her personality. The traditional understanding of school readiness is different from the current one, which we present in this paper. Our aim was to emphasize the importance of the emotional-motivational component of school readiness, which determines the level of school motivation of new pupils. The research study draws attention to the social, cognitive and moral motive of the selected component. As it turned out, the individual motives are present in the structure of the emotional-motivational component of the school readiness of the first year pupils. The development of the motivational sphere must not be neglected, because, as part of the formed personality qualities, it depends on adapting to new conditions at the beginning of schooling.

\section{References}

Astbury, B. (2009). Evaluation of Transition: A Positive Start to School Pilots. Melbourne: Centre for Program Evaluation. Available at http://www.eduweb.vic.gov.au/edulibrary/public/earlychildhood/learning/transitionevaluationreport.pdf

Boethel, M. (2004). Readiness: School, Family and Community. Southwest Educational Development Laboratory. Available at http://www.sedl.org/connections/resources/readiness-synthesis.pdf

Borbélyová, D. (2014). Pripravenost' diet'at'a na vstup do školy.[The child's readiness to enter school] In Borbélyová, D., Špernáková, B. 2014. Testovanie školskej pripravenosti v pedagogickom kontexte. [Testing of school readiness in the educational process] Bratislava: Metodicko-pedagogické centrum. 2014. 17 - 34, Available at https://mpcedu.sk/sites/default/files/projekty/vystup/borbelyova_spernakova_3_0.pdf

Bezruchin, M. M., Jefimovova, S. P. 2000. Rebjonok idjet v školu.[Child is going to school] Moskva: Academia

Božovič, A. (1968). Ličnost' i jevo formirovanije v detskom vozroste. [Personality and its formatting in childhood] Moskva: Prosveščenije

Burvyté, S. 2011. Individual's resistance to social crises is acquired in childhood. Journal of Pedagogy and Psychology 4, p. 17 - 25 Available at: file:///C:/Users/HP/Desktop/v10195-011-0041-6.pdf

El'konin, D. B. (1998). Izbrannije psichologičeskije trudy. [Selective psychology works] Moskva: Pedagogika.

Fabian, H. (2012). Children Starting School. A guide to successful transitions and transfers for teachers and assistants. New York: Routledge. Available at

https://books.google.sk/books?id=reGOAQAAQBAJ\&pg=PA1\&lpg=PA1\&dq=Children+Starting+School.+A+guide+to+suc cessful+transitions+and+transfers+for+teachers+and+assistants\&source=bl\&ots=I7FzHx0OJS\&sig=ACfU3U3RK8KolE9Vt LHIBAtJP5uAJ96Fg\&hl=sk\&sa=X\&ved=2ahUKEwiRo42Rv8LiAhUFY1AKHYmJCJYQ6AEwB3oECAgQAQ\#v=onepage $\& q=$ Children $\% 20$ Starting $\% 20$ School. $\% 20 \mathrm{~A} \% 20$ guide $\% 20$ to $\% 20$ successful $\% 20$ transitions $\% 20$ and $\% 20$ transfers $\% 20$ for $\% 20 \mathrm{t}$ eachers\%20and\%20assistants\&f=false

Fabian, H., Dunlop, A. W. 2007. Outcomes of good practice in transition processes for children entering primary school. Working Paper 42. Hague: Bernard van Leer Foundation. Available at: http://www.bibalex.org/Search4Dev/files/282611/114948.pdf

Franclová, M. (2013). Zahájení školní docházky. [Starting school] Praha: Grada Publishing.

Gavora, P. 2012. Tvorba výskumného nástroja pre pedagogické bádanie. [Creation of a research tool for pedagogical research.] Bratislava: Slovenské pedagogické nakladatel'stvo. Available at: file://C:/Users/HP/Downloads/1-GavoraTvorba-vyskumneho-nastroja\%20PDF.pdf 
Griebel, W., Niesel, R. 2000. The children's voice in the complex transition into Kindergarten and school, Paper presented at 10th European Conference on Quality in Early Childhood Education "Complexity, Diversity and Multiple Perspectives in Early Childhood Services", London 29 August - 1 September 2000, Available at: https://extranet.education.unimelb.edu.au/LED/tec/pdf/griebelniesel1.pdf

Halle, G. T. et al. (2012). Profiles of school readiness among four-years-old Head Start Children. Early Childhood Research Quaterly. 27, 613-626. Available at http://mnprek-3.wdfiles.com/local--files/head start/SR\%20among\%204\%20yr\%20old\%20HS\%20children.pdf

Kasáčová, B., Cabanová, M. (2011). Pedagogická diagnostika: Teória a metódy diagnostikovania v elementárnej edukácii. [Pedagogical diagnostics: Theory and methods of diagnostics in elementary education ]Banská Bystrica: Pedagogická fakulta UMB.

Kovalevová, L. M., Tarasenko, N. N. 1990. Psychologičeskij analyz osobennosti adaptaciji pervoklasnikov k škole. [Psychological analysis of personality in adaptation pupils to school] In: Načalnaja škola, [Elementary school] č. 2, s. 271281

Marko, J. 1971. Vpravovanie sa diet'at’a do školského prostredia. [Putting a child in the school environment] Bratislava: SPN Matthews, D. M. 2008. Positive psychology: Adaptation, Leadership and Performance in Exceptional Circumstantes. In: HANCOCK, A. P. - SZALMA, L. J. (eds.) 2008. Performance Under Stress. England: Ashgate Publishing. Available at https://books.google.sk/books?hl=sk\&lr=\&id=NxBC87g5Mx4C\&oi=fnd\&pg=PA163\&dq=positive+psychology+adaptation \&ots=qztkgp6hHP\&sig=TdWrmtaAJNxu2s4nhhSeAG1JQYY\&redir_esc=y\#v=onepage\&q=positive\%20psychology\%20ada ptation $\& \mathrm{f}=$ false

Niesel, R., Griebel, W. 2001. Transtion to school child: What children tell us about school and what they teach us. Paper presented at the 11th European Conference on Quality on Early Childhood Education. Alkmaar, The Netherlands, 29 August - 1 September.Available at: https://extranet.education.unimelb.edu.au/LED/tec/pdf/griebelniesel4.pdf

Polivanova, K. N. (2009) Šestiletki. Diagnostika gotovnosti k škole. [Six years. Diagnostics of readiness to school] Moskva: EKSMO.

Slezáková, T., Borbélyová, D. (2013). Dimenzie školskej pripravenosti v kontexte inovácií. [Dimensions of school readiness in the context of innovation] In Miňová, M. (ed.) Predprimárne vzdelávanie v kontexte súčasných zmien. Zborník z vedecko odbornej konferencie s medzinárodnou účast’ou. [Pre-primary education in the context of current changes. Proceedings of the scientific-professional conference with international participation] Prešov: Pedagogická fakulta Prešovskej univerzity v Prešove. 108 - 119 Available at http://omep.sk/wp-content/uploads/2013/03/PREDPRIMARNE-VZDELAVANIE-vkontexte-sucasnych-zmien.pdf

Slezáková, T., Tirpáková, A. (2006). Adaptácia diet’at’a na školu - Súčasné pohl’ady na pedagogickú teóriu a prax. [Child adaptation to school - Contemporary perspektives of pedagogical theory and practice] Nitra: PF UKF v Nitre.

Slezáková, T. (2009). Od diet’at’a k školákovi. [From child to pupil] In Kurincová,V.,Slezáková, T. Žiak na začiatku školskej dochádzky. Edukačná podpora učitel'ov a rodičov.[Pupil at the beginning of school. Educational support for teachers and parents] Nitra: PF UKF v Nitre.

Slezáková, T. (2012). Učebno - poznávacia činnost’ detí v najstaršej vekovej skupine materskej školy ako dôležitý predpoklad úspešného zvládnutia roly školáka.[Cognitive aktivity of children in the oldest age group at kindergarten as a important prerequisite for successfully mastering the role of pupil] In Miňová, M. (ed.) Predprimárne vzdelávanie $v$ súčasnosti. Zbornik z vedecko - odbornej konferencie.[Pre-primary education in the context of current changes. Proceedings of the scientific-professional conference with international participation] Prešov: Pedagogická fakulta Prešovskej univerzity v Prešove. 123 - 131 Available at http://omep.sk/wpcontent/uploads/2013/03/ZBORNIKHLOHOVECWEB.pdf

Vágnerová, M. 1997. Psychologie školního dítěte. [Psychology of school child]Praha: Karolinum

Vilčinskaja, T.P. 2000. Psixhologičeskije problémy dezadaptacii detej mladšego škol'nogo vozrastu.[Psychological problems of incorrect adaptation of children in younger school age] Moskva: Prosvečšenije 